\title{
Oropharyngeal Cancer pT1 TNM Finding v6 and v7
}

National Cancer Institute

\section{Source}

National Cancer Institute. Oropharyngeal Cancer pT1 TNM Finding v6 and v7. NCI

Thesaurus. Code C64440.

Oropharyngeal cancer with tumor size 2 centimeters or less in greatest dimension. (from AJCC 6th and 7th Eds.) 